Vol. 4: 397-405.

\title{
Predicting herbage mass of Phleum pratense L. pastures with a disk meter
}

\author{
Perttu Virkajärvi and Kaisa Matilainen \\ Agricultural Research Centre of Finland, East Finland Research Unit, Karelia Research Station, \\ FIN-82600 Tohmajärvi, Finland
}

\begin{abstract}
A simple disk meter was calibrated for predicting the herbage mass (HM) of rotationally grazed pastures dominated by Phleum pratense L. in 1991-1992. A total of 696 paired observations were made on disk height $(\mathrm{DH})$ and $\mathrm{HM}>4 \mathrm{~cm}$. The samples were classified for three different statuses: spring growth, post grazing and aftermath. In 1991 three different disk weights (c. 3.5, 5.0 and 6.5 $\mathrm{kg} / \mathrm{m}^{2}$ ) were compared and the lightest disk was chosen for further studies in 1992. The variation in HM was adequately explained by linear models. There were only small differences between the predictive ability of different disk weights, the lightest disk having the highest $\mathrm{r}^{2}$ values. Post grazing and aftermath samples could be pooled, whilst spring growth samples needed a separate model. Year had no significant effect on the parameters of any model. The models chosen were: spring growth $\mathrm{HM}=-406.7+113.4(\mathrm{DH}) ; \mathrm{r}^{2}=0.95$, post grazing and aftermath $\mathrm{HM}=-629.1+122.1(\mathrm{DH}) ; \mathrm{r}^{2}=$ 0.88 . The disk meter is a potential tool for predicting the $\mathrm{HM}$ of rotationally grazed timothy pastures.
\end{abstract}

Key words: biomass estimation, rising plate, double sampling methods, grassland management, grazing

\section{Introduction}

Herbage mass ( $\left.\mathrm{HM} ; \mathrm{kg} \mathrm{ha}^{-1}\right)$ or an expression reflecting it is an essential factor in interpreting the animal response in grazing experiments. HM is also needed for understanding grassland responses to different management practices. Due to the considerable variability within a grazed sward, a large number of direct samples are often needed to get reliable HM estimates. To overcome the need for large sample numbers and to find nondestructive methods for $\mathrm{HM}$ estimation several procedures have been developed, e.g. visual estimation, determination of sward height with a ruler or a disk meter, measurements with a capacitance meter and spectral analysis (Frame 1981, Burns et al. 1990). The disk meter is cheap and both simple and quick to use. A number of studies have indicated good relationship between HM and disk meter readings (e.g. Powell 1974, Castle 1976, Bransby et al. 1977, Griggs and Stringer 1988, Mould 1990). Since the disk meter is easy to construct (e.g. Castle 1976), its 


\section{AGRICULTURAL SCIENCE IN FINLAND}

\section{Virkajärvi, P. \& Matilainen, K.: Predicting herbage mass of Phleum pratense L....}

price will depend on the components available; costs are minimal in any case. According to Castle (1976) and Bransby et al. (1977), 50 readings can be taken in 10-15 minutes from a paddock 1.6-2.5 ha in size. Even including the time for calibration, the disk meter is still preferred to the clipping method when estimating the HM of large areas (e.g. Vartha and Matches 1977, Earle and McGowan 1979, Griggs and Stringer 1988).

Most studies on non-destructive sampling methods have been conducted on swards consisting of perennial ryegrass (Lolium perenne L.) with or without white clover (Trifolium repens L.) (e.g. Powell 1974, Castle 1976, Michell and Large 1983, Piggot 1989, Gabriels and van der Berg 1992). Several reports of HM estimation of tall fescue swards (Festuca arundinaceae Schreb.) have also been published (Bransby et al. 1977, Vartha and Matches 1977, Bryan et al. 1989).

Finnish pastures differ from those reported in previous disk meter experiments in terms of species composition, sward structure and management practices. The most common species are timothy (Phleum pratense L.) and meadow fescue ( $F$. pratensis Huds.); cocksfoot (Dactylis glomerata L.) is used to some extent. Due to species composition, rapid spring growth, rapid generative development during the long days of summer and the rotational grazing system, tiller number remains low, from 2000-2500 (Huokuna 1964) to 8000 tiller $\mathrm{m}^{-2}$, with large variations within a single paddock. The leaf area index (LAI) also remains relatively low (Virkajärvi, manuscript). The height of the stand of pregrazed swards is usually higher than that reported in most previous disk meter studies. Thus, it was necessary to clarify the prediction ability of the disk meter on rotationally grazed pastures dominated by timothy, Phleum pratense L., under Nordic conditions. First, different disk weights were compared to establish the most suitable downward pressure for timothy. The stability of calibration in the course of the grazing season and between grazing seasons was studied in the following year.

\section{Material and methods}

The disk meter was calibrated by developing regression equations between the meter readings $(\mathrm{cm})$ and herbage mass $\left(\mathrm{kg} \mathrm{ha}^{-1} \mathrm{dm}>4.0 \mathrm{~cm}\right)$ at the Karelia Research Station in 1991 and 1992. The pastures, which were rotationally grazed by suckler cows, contained $80-90 \%$ timothy and 0 $20 \%$ meadow fescue. The amount of dicotyledonous weeds was insignificant. The pastures were fertilized with $170-180 \mathrm{~N}, 20-40 \mathrm{P}$ and 140-210 K depending on the soil properties. Climatic data were recorded at the Karelia Research Station. In all, 18 series of calibrations were made between 30th May 1991 and 15th September 1992. The calibration included spring growth, post-grazed swards and aftermath, later referred to as field status.

\section{Comparison of three disk weights with accuracy of the method}

The disk meter was constructed as described in Castle (1976). It consisted of a plastic rod (1100 mm long, $22 \mathrm{~mm}$ diameter) and two freely sliding aluminium plates ( $1 \mathrm{~mm}$ thick) joined together. The diameter of the lower aluminium disk was $300 \mathrm{~mm}$. Additional brass weights were used to give weight of 247,354 and $458 \mathrm{~g}$ to correspond to weights of c. $3.5,5.0$ and $6.5 \mathrm{~kg} / \mathrm{m}^{2}$. The rod was graduated in $1 \mathrm{~cm}$ intervals. For measurements of HM, the meter was held upright and then pushed into the vegetation. The horizontal plate was raised by the vegetation, and the settling height was read from the rod with $0.5 \mathrm{~cm}$ accuracy.

The available $\mathrm{HM}$ was determined by cutting $0.225 \mathrm{~m}^{2}$ quadrats to a height of $4.0 \mathrm{~cm}$ with electric garden shares. Before the cutting, three disk meter readings (DH) were taken of each quadrat at each disk weight and the mean was pooled against HM. In addition, extended height (SH) was measured with a ruler, and sward density (DEN) was determined visually as percentages of full tiller density. The dry matter content (DM) 
Vol. 4: 397-405.

Table 1. Monthly mean temperatures and precipitation during growing seasons 1991 and 1992 and average long-term values.

\begin{tabular}{lrrrrrrr}
\hline & \multicolumn{3}{c}{ Mean temperature, ${ }^{\circ} \mathrm{C}$} & & \multicolumn{3}{c}{ Precipitation, mm } \\
\cline { 2 - 3 } \cline { 7 - 8 } & 1991 & 1992 & $1961-1990$ & & 1991 & 1992 & $1961-1990$ \\
\hline May & 7.6 & 9.5 & 8.6 & & 41 & 18 & 36 \\
June & 13.3 & 14.5 & 14.0 & & 117 & 40 & 57 \\
July & 16.1 & 14.8 & 15.9 & & 124 & 54 & 70 \\
August & 14.5 & 13.3 & 13.5 & & 130 & 105 & 80 \\
September & 8.0 & 11.3 & 8.3 & & 80 & 46 & 65 \\
\hline
\end{tabular}

was determined by force-drying samples at $100^{\circ} \mathrm{C}$ for 20 hours. In order to describe the material more precisely, a representative sample was collected on each occasion, and crude protein (CP) and crude fibre (CF) were determined at the Central Laboratory, Agricultural Research Centre, Jokioinen, according to standard procedures.

The data were split according to Neter et al. 1989 , i.e. about two-thirds of the observations were used to develop estimation equations (estimation data set) and the remaining third were used for validation (validation data set). For the comparison of disk weights made in 1991, HM prediction equations were developed from the data of calibrations $1,3,4,5,7$ and 9. The remaining calibrations (2, 6 and 8$)$, one of each field status, were used for validation.

The HM prediction models were developed by SAS GLM and REG procedures (SAS Institute 1985) on the basis of residual diagnostics (Henderson and Velleman 1981), $\mathrm{r}^{2}$ and residual standard deviation (RSD). For the comparison of disk meter weights, the original $\mathrm{HM}$ model had field status (ST), calibration (CAL) and DH and all possible interactions of these as variables. The terms which were not significant in the regression model at the 0.05 level were excluded stepwise. Quadratic models $\left(\mathrm{Y}=\mathrm{DH}+\mathrm{DH}^{2}\right)$ were studied to test curvilinearity. Logarithmic $(\log (\mathrm{Y})=\mathrm{DH})$ models were also studied to satisfy the equal variance assumption.

The prediction equations developed were applied to the validation data, i.e. the remaining third of observations. The accuracy of prediction models was studied by comparing the predicted values of $\mathrm{HM}$ with their corresponding clipped HM values in terms of $\mathrm{r}^{2}$, and the standard error of validation (SEV). SEV is defined as: $\left[\sum\left(Y_{i}-\hat{Y}_{i}\right)^{2} / n\right]^{1 / 2}($ Griggs and Stringer 1988).

\section{Accuracy of light disk in $|99|-1992$}

To determine the accuracy of the disk meter over the years, measurements were continued in 1992 with the lightest disk only. To ensure the representativeness of the estimation data set, the samples were classified in the field into weak, average and strong vegetation, including extreme sites in estimation data set (Bransby and Clarke 1988). The proportions of each class in the estimation data set were approximately the same. The original HM model had year (YR), ST, CAL and $\mathrm{DH}$ and all possible interactions of these as variables. The procedure continued as described previously.

\section{Results}

The weather conditions are presented in Table 1. There were marked differences in growing seasons: 1991 was extremely wet but in 1992 the pastures suffered from drought.

$\mathrm{HM}$ and $\mathrm{SH}$ varied a great deal during the 
Virkajärvi, P. \& Matilainen, K.: Predicting herbage mass of Phleum pratense L. ...

Table 2. Date, number of paired observations, field status, yields of clipped samples, extended sward height and crude fibre content for 18 series of calibrations.

\begin{tabular}{|c|c|c|c|c|c|c|c|}
\hline \multicolumn{3}{|c|}{ Calibration } & \multirow[t]{2}{*}{$\begin{array}{l}\text { Field } \\
\text { status* }\end{array}$} & \multicolumn{2}{|c|}{$\begin{array}{c}\text { Herbage mass }>4 \mathrm{~cm} \\
\mathrm{~kg} / \mathrm{ha} \mathrm{DM}\end{array}$} & \multirow{2}{*}{$\begin{array}{c}\begin{array}{c}\text { Sward height } \\
\mathrm{cm}\end{array} \\
\text { Mean }\end{array}$} & \multirow{2}{*}{$\begin{array}{c}\text { Crude fibre } \\
\% \\
\text { Mean }\end{array}$} \\
\hline No. & Date & $\mathrm{n}$ & & Mean & Range & & \\
\hline \multicolumn{8}{|c|}{1991} \\
\hline 1 & 30.5 & 30 & SPGR & 705 & $271-1151$ & 20 & 16 \\
\hline 2 & 4.6 & 25 & SPGR & 1400 & $507-2413$ & 29 & 22 \\
\hline 3 & 11.6 & 25 & SPGR & 2251 & $996-4187$ & 40 & 23 \\
\hline 4 & 2.7 & 22 & POSTG & 1387 & $18-3240$ & 26 & 33 \\
\hline 5 & 23.7 & 33 & AFT & 999 & $62-1938$ & 29 & 24 \\
\hline 6 & 30.7 & 26 & POSTG & 728 & $156-2040$ & 15 & 26 \\
\hline 7 & 26.8 & 33 & POSTG & 194 & $18-840$ & 8 & 24 \\
\hline 8 & 27.8 & 28 & AFT & 508 & $22-2280$ & 17 & 23 \\
\hline 9 & 3.9 & 30 & AFT & 385 & $58-889$ & 16 & 21 \\
\hline \multicolumn{8}{|c|}{1992} \\
\hline 10 & 3.6 & 50 & SPGR & 715 & $89-1631$ & 19 & 17 \\
\hline 11 & 9.6 & 50 & SPGR & 1404 & $396-2649$ & 22 & 17 \\
\hline 12 & 23.6 & 49 & SPGR & 4436 & $2627-7107$ & 53 & 28 \\
\hline 13 & 2.7 & 48 & POSTG & 1203 & 9-3747 & 19 & 27 \\
\hline 14 & 15.7 & 49 & AFT & 750 & $187-1782$ & 17 & 21 \\
\hline 15 & 21.7 & 50 & POSTG & 622 & $13-1773$ & 12 & 23 \\
\hline 16 & 31.8 & 49 & AFT & 510 & $18-2169$ & 14 & 21 \\
\hline 17 & 14.9 & 49 & AFT & 1026 & $40-3098$ & 20 & 22 \\
\hline 18 & 15.9 & 50 & POSTG & 733 & $40-1880$ & 13 & 23 \\
\hline
\end{tabular}

Total

696

* Field status: $\mathrm{SPGR}=$ spring growth, $\mathrm{POSTG}=$ post grazing, $\mathrm{AFT}=$ aftermath.

experimental period. Maximum $\mathrm{HM}, 7107 \mathrm{~kg} \mathrm{ha}^{-1}$ DM, was obtained on 23rd June, 1992. The mean sward height of 11th June, $1991,40 \mathrm{~cm}$, and that of 23rd June, 1992, $53 \mathrm{~cm}$, are both clearly higher than recommended as a grazing stage in Finland. CF content was moderate, exceeding $26 \%$ on only three occasions (Table 2).

DH readings correlated better with $\mathrm{SH}(\mathrm{r}=$ $0.92, \mathrm{p}<0.0001)$ than with DEN $(\mathrm{r}=0.14$, $\mathrm{p}<0.0001)$. HM correlated slightly better with DH $(r=0.97, p<0.0001)$ than SH alone $(r=$ $0.93, \mathrm{p}<0.0001)$. The correlation between HM and DEN was weak $(r=0.17, p<0.0001)$, being stronger in spring growth $(\mathrm{r}=0.36 \mathrm{p}<0.0001)$ than in aftermath samples $(r=0.16, p<0.01)$. In post grazing samples the correlation was weak and statistically not significant $(r=0.08$, $\mathrm{p}>0.05$ ).

\section{Effect of disk weight on accuracy of the method}

The variation in HM was adequately explained by linear models. The data on after grazing and aftermath samples could be pooled, but those on first-growth samples had to be analysed separately. The results of the comparison were published as a poster at European Grassland Federation's XIV General Meeting 1992 (Virkajärvi et al. 1992). The differences in accuracy of the 
Vol. 4: 397-405.

Table 3. Selected available HM prediction models ${ }^{*}$ for three disk meters, light $(\mathrm{L})$, medium $(\mathrm{M})$ and heavy $(\mathrm{H})$.

\begin{tabular}{|c|c|c|c|c|c|c|c|c|c|}
\hline \multicolumn{7}{|c|}{ Calibration } & \multicolumn{3}{|c|}{ Validation } \\
\hline $\begin{array}{l}\text { Disk } \\
\text { type }\end{array}$ & $\mathrm{n}$ & $\begin{array}{c}\text { Mean Y } \\
\mathrm{kg} / \mathrm{ha}\end{array}$ & $\begin{array}{c}\mathrm{a} \pm \mathrm{SE} \\
\mathrm{kg} / \mathrm{ha}\end{array}$ & $\begin{array}{l}\mathrm{b} \pm \mathrm{SE} \\
\mathrm{kg} / \mathrm{ha}\end{array}$ & $\mathrm{R}^{2}$ & $\begin{array}{l}\text { RSD } \\
\mathrm{kg} / \mathrm{ha}\end{array}$ & $\mathrm{n}$ & $\mathrm{R}^{2}$ & $\begin{array}{l}\mathrm{SEV} \\
\mathrm{kg} / \mathrm{ha}\end{array}$ \\
\hline \multicolumn{10}{|c|}{ Spring growth samples: } \\
\hline $\mathrm{L}$ & 55 & 1408 & $-868.2 \pm 93.7$ & $140.0 \pm 5.4$ & 0.93 & 257.0 & 25 & 0.90 & 165.6 \\
\hline M & & & $-814.5 \pm 96.5$ & $150.6 \pm 6.1$ & 0.92 & 269.4 & & 0.87 & 197.1 \\
\hline $\mathrm{H}$ & & & $-727.8 \pm 90.7$ & $157.7 \pm 6.2$ & 0.92 & 262.3 & & 0.85 & 206.6 \\
\hline \multicolumn{10}{|c|}{ Post grazing and aftermath samples: } \\
\hline $\mathrm{L}$ & 118 & 690 & $-502.8 \pm 37.6$ & $103.5 \pm 2.8$ & 0.92 & 202.3 & 54 & 0.64 & 303.8 \\
\hline M & & & $-469.2 \pm 37.2$ & $109.8 \pm 3.0$ & 0.92 & 204.1 & & 0.63 & 309.0 \\
\hline $\mathrm{H}$ & & & $-484.8 \pm 37.6$ & $122.2 \pm 3.4$ & 0.92 & 204.6 & & 0.63 & 309.9 \\
\hline \multicolumn{10}{|c|}{ Combined calibrations: } \\
\hline $\mathrm{L}$ & 173 & 918 & $-627.6 \pm 42.0$ & $118.6 \pm 2.8$ & 0.91 & 258.1 & 79 & 0.84 & 251.6 \\
\hline M & & & $-589.0 \pm 43.0$ & $126.8 \pm 3.2$ & 0.90 & 269.1 & & 0.83 & 261.8 \\
\hline $\mathrm{H}$ & & & $-588.1 \pm 40.8$ & $138.7 \pm 3.3$ & 0.91 & 256.5 & & 0.82 & 268.0 \\
\hline
\end{tabular}

"Model terms: $\mathrm{HM}=$ herbage mass (dry matter $\mathrm{kg} / \mathrm{ha}>4 \mathrm{~cm}), \mathrm{DH}=$ disk height $(\mathrm{cm}) . \mathrm{n}=$ number of observations used for calibration and validation, $\mathrm{SE}=$ standard error of estimate, $\mathrm{RSD}=$ residual standard deviation, $\mathrm{SEV}=\mathrm{standard}$ error of validation (defined as: $\left[\Sigma\left(\mathrm{Y}_{i} \hat{\mathrm{Y}}_{\mathrm{i}}\right)^{2} / \mathrm{n}\right]^{1 / 2}($ Griggs and Stringer 1988).

method between three disk weights were small (Table 3). The effect of disk weight was strongest in spring growth. The light disk (L) was slightly the most reliable in terms of $\mathrm{r}^{2}$ and SEV on all occasions and was therefore chosen for sampling in 1992.

\section{Accuracy of light disk in 1991-1992}

The original HM model had YR, ST, CAL and $\mathrm{DH}$ and all possible interactions of these as variables. Year and calibration or their interactions were not significant ( $p>0.05$ ) terms in the model. As in the case of different disk weights, the variation in $\mathrm{HM}$ was adequately explained by linear models. Use of quadratic instead of the linear models did not markedly improve $\mathrm{r}^{2}$ values (from 0.948 to 0.952 ). The data on after grazing and aftermath samples could be pooled, but the first growth samples had to be analysed separately. The HM estimation models chosen are presented in Table 4. The accuracy of the meth- od was good in spring growth and slightly poorer in post grazing and aftermath.

\section{Discussion}

\section{Effect of disk weight on accuracy of the method}

The downward pressures used, 3.5-6.5 kg/m², were rather average when compared with those reported in other studies, in which pressures have varied from 2.9 (Castle 1976, Mould 1992) to $15 \mathrm{~kg} \mathrm{~m}^{-2}$ (Bransby et al. 1977). Downward pressure did not affect the accuracy of the method but only the slope of the regression line. Here, timothy pasture resembles tall fescue (Bransby et al. 1977). The light disk gave a slightly more accurate result than the other disks. Thus it would seem sensible to study lighter rather than heavier disks, as also suggested by Mould (1992). 
Virkajärvi, P. \& Matilainen, K.: Predicting herbage mass of Phleum pratense L....

Table 4. Selected HM prediction models* for the light disk 1991-1992.

\begin{tabular}{|c|c|c|c|c|c|c|c|c|c|}
\hline \multicolumn{7}{|c|}{ Calibration } & \multicolumn{3}{|c|}{ Validation } \\
\hline & $\mathrm{n}$ & $\begin{array}{c}\text { Mean Y } \\
\mathrm{kg} / \mathrm{ha}\end{array}$ & $\begin{array}{l}\mathrm{a} \pm \mathrm{SE} \\
\mathrm{kg} / \mathrm{ha}\end{array}$ & $\begin{array}{l}\mathrm{b} \pm \mathrm{SE} \\
\mathrm{kg} / \mathrm{ha}\end{array}$ & $\mathrm{R}^{2}$ & $\begin{array}{l}\text { RSD } \\
\mathrm{kg} / \mathrm{ha}\end{array}$ & $\mathbf{n}$ & $\mathrm{R}^{2}$ & $\begin{array}{l}\text { SEV } \\
\mathrm{kg} / \mathrm{ha}\end{array}$ \\
\hline SPGR & 152 & 1894 & $-406.7 \pm 48.2$ & $113.4 \pm 2.0$ & 0.95 & 329.5 & 77 & 0.95 & 345.4 \\
\hline POSTG & 149 & 794 & $-587.2 \pm 45.5$ & $120.3 \pm 3.5$ & 0.88 & 258.3 & 80 & 0.87 & 287.4 \\
\hline AFT & 157 & 710 & $-692.2 \pm 47.3$ & $126.8 \pm 4.0$ & 0.87 & 202.5 & 81 & 0.90 & 177.0 \\
\hline POSTG+AFT & 306 & 751 & $-629.1 \pm 32.1$ & $122.1 \pm 2.6$ & 0.88 & 231.7 & 161 & 0.88 & 239.5 \\
\hline ALL & 458 & 1130 & $-546.1 \pm 22.5$ & $117.6 \div 1.3$ & 0.94 & 273.0 & 238 & 0.94 & 287.4 \\
\hline
\end{tabular}

"Model terms: $\mathrm{HM}=$ herbage mass (dry matter $\mathrm{kg} / \mathrm{ha}>4 \mathrm{~cm}), \mathrm{DH}=$ disk height $(\mathrm{cm}) . \mathrm{n}=$ number of observation, $\mathrm{SE}=$ stadard error of estimate, RSD = residual standard deviation, $\mathrm{SEV}=$ standard error of validation (defined as: $\left[\Sigma\left(Y_{i}-\hat{Y}_{i}\right)^{2} / n\right]^{1 / 2}($ Griggs \& Stringer 1988).

\section{Accuracy of the light disk meter}

In terms of accuracy of the method or residual deviation, the variation in HM was adequately described as a linear function of DH, although the residuals tended to increase as DH increased (Fig. 1). Logarithmic models were not suitable. Although there was a slight tendency to curvilinearity in the validation set of spring growth samples (Fig. 1a.), the quadratic model did not markedly improve the $\mathrm{r}^{2}$ value (less than $1 \%$ unit). This is probably due to the robustness of the linear model and the sensitivity of the quadratic model to differences between the estimation and the validation data set. The relationship between $\mathrm{DH}$ and $\mathrm{HM}$ remained linear even though the height of the stand was above the normal range for pastures. From the literature it can be concluded that linear functions have been used when the $\mathrm{DH}$ values have been relatively low, but at high DH values $(>40 \mathrm{~cm})$ a polynomial function has been more accurate (Bransby et al. 1977, Baker et al. 1981). It is clear that when the average height increases, the risk of lodging also increases, thus causing considerable error. The method may not, therefore, be suitable for estimating, say, silage yield if lodging is abundant. The accuracy of the method is also strongly impaired if the grass is trampled or if the soil surface is uneven.

The $\mathrm{r}^{2}$ values found here were relatively high, which may be attributed to the uniform botanical composition (up to $90 \%$ of timothy). SEV, too, was low, 345 and $240 \mathrm{~kg} \mathrm{ha}^{-1}$ DM (Table 4), but because of low HM, the coefficient of variation was high. This may restrict the usefulness of the method, especially when measuring HM after grazing. However, the cutting height, $4 \mathrm{~cm}$, lowered the HM values observed compared with those for clipping to ground level.

Density correlated only very weakly with HM. This could be partly due to the fact it was estimated visually, but the correlation was low with more accurate methods, too (Urioste 1984, Griggs and Stringer 1988). It is interesting to note that DH correlated clearly better with $\mathrm{SH}$ $(\mathrm{r}=0.92, \mathrm{p}<0.0001)$ than with DEN $(\mathrm{r}=0.14$, $\mathrm{p}<0.0001)$. The inclusion of density in the HM prediction models did not improve the accuracy of prediction.

According to several researchers, the disk meter should be calibrated several times during the growing season and again in different years (e.g. Bransby 1977 et al., Vartha and Matches 1977, Bryan et al. 1989, Mould 1990) because of changes in the botanical composition of the sward and differences in vegetative and generative growth type. Here, the parameters of the spring growth model differed from those of post grazing and aftermath. Other differences in the course of the growing season were not found, possibly because botanical composition was uni- 
Vol. 4: 397-405.

$\mathrm{HM}, \mathrm{kg} / \mathrm{hadm}>4 \mathrm{~cm}$

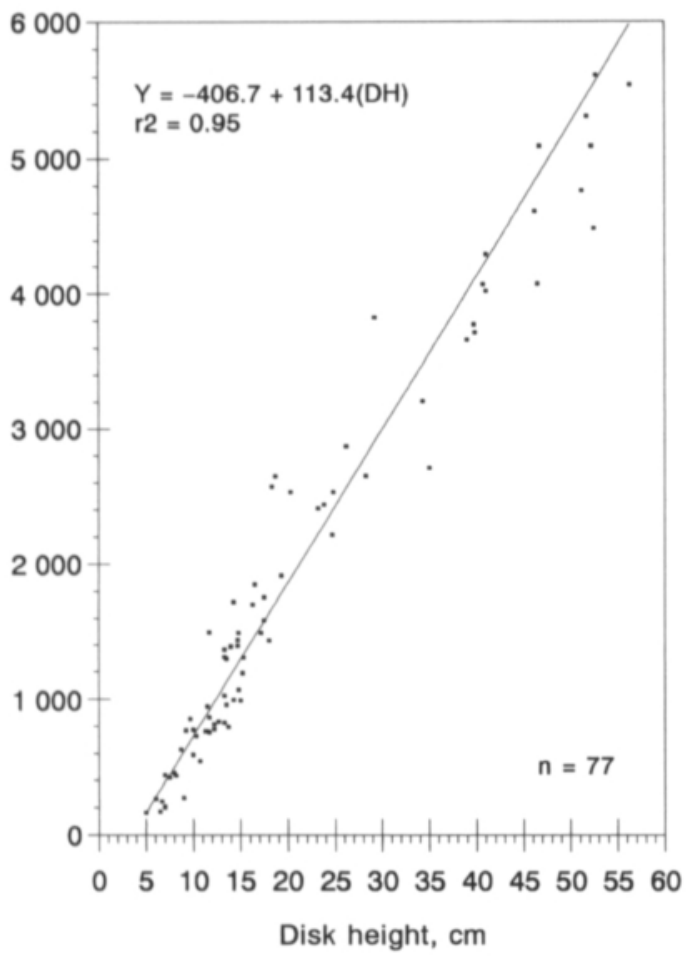

$\mathrm{HM}, \mathrm{kg} / \mathrm{ha} \mathrm{dm}>4 \mathrm{~cm}$

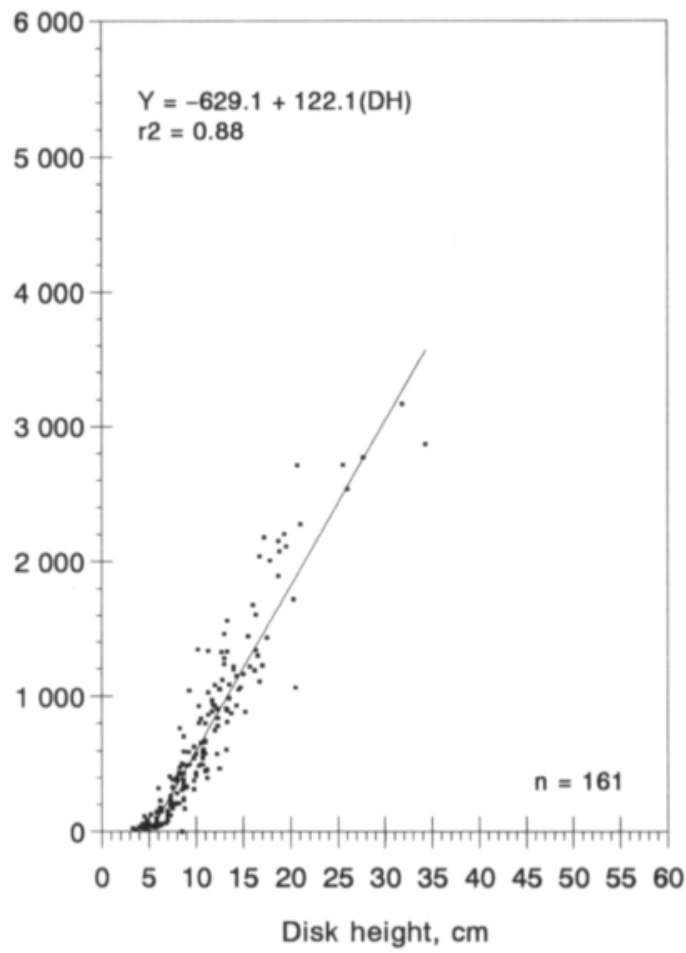

Fig. 1. Relationship between disk height $(\mathrm{DH})$ and dry matter herbage mass $(\mathrm{HM})$ samples for 1991-1992. Solid line = estimated HM. a) Spring growth b) post grazing and aftermath.

form throughout the growing season. Moreover, the cutting height of $4 \mathrm{~cm}$ may have affected the results, as herbage often accumulates under the grazing horizon in the course of the grazing season. The nearer the sampling height and the lower limit of the actual grazing horizon are to each other, the less effect this accumulation should have.

Uniform botanical composition is the most probable reason for there being no statistical differences between years, even though 1991 was extremely moist whilst 1992 was dry, and swards clearly suffered from drought. Thus turgor pressure of the leaves or plants appears to have had only a slight effect on the parameters of the regression line. Many researhers have concluded that there is no uniform calibration equation (Griggs and Stringer 1988, Bryan et al. 1989, Gonzalez et al. 1990). Although in this study sta- bility was good under very different moisture conditions, the disk meter should still be calibrated for each occasion if the results are to be expressed as HM. Depending on the purpose of the determinations, the calibration could be done according to Bransby and Clarke (1988) or using the simplified version described by Stockdale (1984).

\section{Conclusions}

The disk meter is accurate enough for predicting the HM of timothy pastures of uniform botanical composition for specific purposes when large paddocks are to be evaluated. Such purposes might be estimation of the effects of overwintering damage on growth in different management practices or estimation of sward growth 
Virkajärvi, P. \& Matilainen, K.: Predicting herbage mass of Phleum pratense L. ...

rate; it can also be used as a tool for management decisions in grazing trials. The disk meter cannot be used to predict the HM of a sward in the event of disturbances in canopy height, e.g. lodging or the presence of old stubble or trampled grass. Sward density is of minor importance to meter readings.
Acknowledgements. The authors would like to thank E. Ketoja, Agricultural Research Centre, Data and Information Services, for statistical advice concerning the effect of different disk weights. We also thank the technical staff of the Karelia Research Station for assistance with measurements and the Central Laboratory of the Agricultural Research Centre for the chemical analysis.

\section{References}

Baker, B.S., Eynden, T.V. \& Boggess, N. 1981. Hay yield determinations of mixed swards using a disk meter. Agronomy Journal 73: 67-69.

Bransby, D.I. \& Clarke, G.P. 1988. Biological, practical and statistical considerations associated with measuring forage availability in grazing trials. Proceedings of the Southern Pasture and Forage Improvement Conference. p. 59-63.

Bransby, D.I., Matches, A.G. \& Krause, G.F. 1977. Disk meter for rapid estimation of herbage yield in grazing trials. Agronomy Journal 69: 393-396.

Bryan, W.B., Thayne, W.V. \& Prigge, E.C. 1989. Use of a disk meter to evaluate continuously grazed pastures. Journal of Agronomy and Crop Science. 163: 44-48.

Burns, J.C., Lippke, H. \& Fisher, D.S. 1990. The relationship of herbage mass and characteristics to animal responses in grazing experiments. In : Grazing research, design, methodology and analysis. CSSA special publication No 16. Madison, USA. p. 7-19.

Castle, M.E. 1976. A simple disc instrument for estimating herbage yield. Journal of the British Grassland Society $31: 37-40$.

Earle, D.F. \& McGowan, A.A. 1979. Evaluation and calibration of an automated rising plate meter for estimating dry matter yield of pasture. Australian Journal of Experimental Agriculture and Animal Husbandry 19: 337-343. Frame, J. 1981. Herbage mass. In: Hodgson, J. et al. (eds.). Sward measurement handbook. British Grassland Society. Maidenhead, UK. p. 39-69.

Gabriels, P.C.J. \& Van Den Berg, J.V. 1993. Calibration of two techniques for estimating herbage mass. Grass and Forage Science 48: 329-335.

Gonzalez, M.A., Hussey, M.A. \& Conrad, B.E. 1990. Plant height, disk and capacitance meters used to estimate bermudagras herbage mass. Agronomy Journal 82: 861-864.

Griggs T.C. \& Stringer W.C. 1988. Prediction of alfalfa herbage mass using sward height, ground cover and disk technique. Agronomy Journal 80: 204-208.

Henderson, H.V. \& Velleman, P.F. 1981. Building multiple regression models interactively. Biometrics 37 : $391-$ 411.

Huokuna, E. 1964. The effect frequency and height of cutting on cocksfoot swards. Annales Agriculturae Fenniae. 3: Suppl. no. 4. 83 p.

Michell, P. \& Large, R.V. 1983. The estimation of herbage mass of perennial ryegrass swards: a comparative evaluation of a rising plate meter and a single probe capacitance meter calibrated at and above ground level. Grass and Forage Science 38: 295-299.

Mould, F.L. 1990. A note on the use of a rising-plate meter to estimate herbage yield. Norwegian Journal of Agricultural Sciences 4: 111-117.

- 1992. Use of a modified rising-plate meter to estimate herbage yield. Norwegian Journal of Agricultural Sciences $4: 111-117$.

Neter, J., Wasserman, W. \& Kutner, M.M. 1989. Applied linear regression models. 2nd ed. 667 p. Boston.

Piggot, G.J. 1989. A comparison of four methods for estimating herbage yield of temperate dairy pastures. New Zealand Journal of Agricultural Research 32: 121123.

Powell, T.L. 1974. Evaluation of weighted disc meter for pasture yield estimation on intensively stocked dairy pasture. New Zealand Journal of Experimental Agriculture 2: $237-241$.

SAS Institute 1985. SAS/STAT guide for Personal Computers, 6th ed. SAS Institute Inc., Cary, NC, USA. 378 p. Stockdale, C.R. 1984. Evaluation of techniques for estimating the yield of irrigated pastures intensively grazed by dairy cow. 2 . The rising plate meter. Australian Journal of Experimental Agriculture and Animal Husbandry 24: 305-311.

Urioste, J. 1984. Utveckling av metoder för skattning av betets avkastning som hjälpmedel för foderstyrning till mjölkkor pá bete. Examenarbete i Husdjurens Utfodring och Vård. 36 p. Sveriges Lantbruksuniversitet. Uppsala. Vartha, E.W. \& Matches, A.G. 1977. Use of a weighteddisk measure as an aid in sampling the herbage yield on tall fescue pastures grazed by cattle. Agronomy Journal 69: 888-890.

Virkajärvi, P., Karvonen, K. \& Ketoja, E. 1992. Calibration of a disk meter for predicting herbage mass of Phleum pratense pastures. Proceedings of the 14th General Meeting of the European Grassland Federation. Lahti, Finland. p. 556-557. 
Vol. 4: 397-405.

\title{
SELOSTUS
}

\section{Timoteivaltaisen laidunnurmen massan määrittäminen mittalautasen avulla}

\author{
Perttu Virkajärvi ja Kaisa Matilainen \\ Maatalouden tutkimuskeskus
}

Laidunkaudella 1991 ja 1992 tutkittiin Maatalouden tutkimuskeskuksen Karjalan tutkimusasemalla mittalautasen käyttökelpoisuutta timoteivaltaisen laidunnurmen kuiva-ainemassan määrityksessä. Käytetty mittalautanen koostui alumiinisesta lautasesta (halkaisija $30 \mathrm{~cm}$ ), joka liikkui pystysuuntaisesti pitkin muovista mittakeppiä. Tutkimuksessa havainnoitiin mittalautasen lukemien ja nurmen massan välisen riippuvuuden luonnetta sekä miten tämä riippuvuus muuttuu kasvukauden aikana ja eri vuosina. Aineisto koostui yhteensä 696 havaintoparista.

Lautasen painon vaikutusta menetelmän tarkkuuteen tutkittiin laidunkaudella 1991. Eri painoisten lautasten kasvustoon kohdistamat paineet olivat $3,5 \mathrm{~kg} / \mathrm{m}^{2}, 5 \mathrm{~kg} / \mathrm{m}^{2}$ ja $6,5 \mathrm{~kg} / \mathrm{m}^{2}$. Mittalautasen paino ei juurikaan vaikuttanut estimointiyhtälöiden tarkkuuteen. Kevein lautanen osoittautui hienokseltaan tarkimmaksi.

Lineaarinen regressio kuvasi parhaiten eri muuttujien välisiä riippuvuuksia. Vaikka vuodet poikke- sivat etenkin sademääriltään toisistaan, ei vuodella tai kalibraatiokerralla ollut vaikutusta parametrien arvoihin vaan aineistot voitiin yhdistää. Yhdistetyssä aineistossa 1991-1992 (kevein lautanen) nurmen kuiva-ainemassa pystyttiin arvioimaan melko tarkasti mittalautasen lukemien perusteella, parhaiten kevătkasvustossa. Estimointiyhtälöiden samankaltaisuuden vuoksi laiduntamisen jälkeiset ja odelmahavainnot voitiin yhdistää.

Nurmen tiheys ja kuiva-ainepitoisuus korreloivat heikosti sadon kanssa, eivätkä ne parantaneet mittalautaslukemiin perustuvaa satomallia oleellisesti. Tutkimuksen perusteella mittalautanen oli riittävän luotettava timoteivaltaisen laidunnurmen massan kuvaajana. Kevätkasvustossa lautanen oli luotettavampi kuin laiduntamisen jälkeen tai odelmassa. Kasvusto ei saa olla lakoontunut eikä tallattu. Menetelmä vaatii lisätutkimusta eri nurmikasvilajeilla ja seosnurmissa, jotta mittalautasta voitaisiin käyttää yleisesti laiduntutkimuksissa. 